Hum. Hered. 1988;38:I-VI

\title{
Contents, Vol. 38, 1988
}

\section{Editors}

L. Beckman, Umeå J. Lindsten, Stockholm

Editorial Board

K. Berg, Oslo

L.L. Cavalli-Sforza, Stanford, Calif.

A. de la Chapelle, Helsinki

J. Dausset, Paris

T.J. David, Manchester

B. Dutrillaux, Paris

F.C. Fraser, Montreal

N. Freire-Maia, Curitiba

J. Frézal, Paris

R. Grubb, Lund PA. Jacobs, New York, N.Y. Margareta Mikkelsen. København F. Mitelman, Lund

N.E. Morton, New York, N.Y.

J. Mohr, København

A.E. Mourant, London

J.V. Neel, Ann Arbor, Mich.

U. Pettersson, Uppsala

Marianne Rasmuson, Umeå

D.L. Rimoin, Los Angeles, Calif.

L.D. Sanghvi, Bombay

M. Siniscalco, New York, N.Y.

F. Vogel, Heidelberg

D.J. Weatherall, Oxford

R.L. White, Salt Lake City, Utah

M. Whittaker, Exeter

Contents Vol. 38,1988

No. 1 Original Paper

Isoelectric Focusing of Superoxide Dismutase: Report of the Unique SOD A*2 Allele in a US White Population

DeCroo, S.; Kamboh, M.I.; Leppert, ML; Ferrell, R.E 1

Study of Possible Genetic Predisposition to Endemic Goitre among the Fur and Baggara

Tribes of the Sudan

Bayoumi, R.A.; Taha, T.S.M.; Saha, N 
Linkage Relations of JK, CO, KEL and IGK with Each Other and with AHCY

Bender, K.; Bissbort, S.; Crone, EL; Senff, H.; Steiert, A.; Neumann, H.; Koch, M.;

Nagel, M.; Wienker, T.F 12

Gc Subtypes in Finns, Swedes and Swedish Lapps

Beckman, L.; Beckman, G.; Nylander, P.0 18

The Anonymous RFLP Locus D1S2 Is Close to PGM1 on Chromosome 1

Kidd, K.K.; Kidd, J.R.; Castiglione, CM.; Sparkes, R.S.; Egeland, J.A.;, Bakker, E. . . 22

Distribution of Alpha-1-Antitrypsin Phenotypes in Sweden

Hjalmarsson, $\mathrm{K} \quad 27$

Relationship between Placental Alkaline Phosphatase Types and Obstetric History of

Mother

Balgir, P.P 31

Use of a Simple Method for the Epstein-Barr Virus Transformation of Lymphocytes from

Members of Large Families of Reunion Island

Ventura, M.; Gibaud, A.; Le Pendu, J.; Hillaire, D.; Gerard, G.; Vitrac, D.; Oriol, R.. 36 Serum

Protein Markers in Systemic Lupus erythematosus

Rantapää Dahlqvist, S.; Beckman, G.; Beckman, L 44

Complement C4 Phenotypes in Dementia of the Alzheimer Type

Eikelenboom, P.; Goetz, J.; Pronk, J.C.; Hauptmann, G 48

C3 Allotypes in Pregnancy Hypertension and Eclampsia

Cooper, D.W.; Deane, E.M.; Marshall, P.; Gallery, E.D.M 52

Short Communications

Transferrin C2 and Radiation-Induced Chromosomal Damage

Beckman, L.; Nordenson, 156

Esterase D Polymorphism in Serbia (Yugoslavia)

Lemic, Z.; Kalimanovska, V.; Jelic-Ivanovic, Z.; Majkic-Singh, N 59

Glyoxalase I Polymorphism in Catalonia (Spain)

Ribó, G.; Mas, J.; Moreno, P 62

Announcement 64

No. 2 Original Paper

Polymorphic Restriction Sites of Type II Collagen Gene: Their Location and Frequencies

in the Finnish Population

Väisänen, P.; Elima, K.; Palotie, A.; Peltonen, L.; Vuorio, E

DNA Polymorphisms, Identified by an X-Chromosome Short-Arm Probe L 1.28 (DXS7),

in Different Racial Groups

Papiha, S.S.; Bhattacharya, S.S.; Roberts, D.F 72

Contents

III

Lyosomal Enzyme Activities Among Chinese: Leukocyte $\alpha$-Galactosidase and $\beta$-Galactosidase Xu, Y.-K.; Ng, W.G 76

Salivary Enzyme Polymorphisms (Set, Sgd and AMY,) in the Galician Population

Boán, F.; Caeiro, J.L.B 83

Factor I (C3b Inactivator) Polymorphism among Five Populations in Eurasia

Yuasa, I.; Umetsu, K.; Suenaga, K.; Ito, K.; Iha, M.; Hirata, H.; Robinet-Lévy, M.;

Inoue, T.; Okada, K 91

Genetic Heterogeneity of Thalassemias in Mexican Mestizo Patients with Hemolytic Anemia 
Ibarra, B.; Vaca, G.; Mora, E. de la; Romero, F.; Aguilar-Luna, C; Mejía, A.; Esparza, M.A.; Perez, G.; Ornelas, M.L.; Cantú, J.M 95

Human Enzyme Polymorphism in the Canary Islands. II. African Influence

Morilla, J.M.; Afonso, J.M.; Hernandez, M.; Pestano, J.J.; Larruga, J.M 101

Polymorphism of Alpha-1-Antitrypsin (Pi) in the Swiss Population Determined by Isoelectric Focusing with an Immobilized $\mathrm{pH}$ Gradient

Bar, W.; Kratzer, A 106

The Le $(a+b+)$ Phenotype in Polynesians

Henry, S.M.; Simpson, L.A.; Woodfield, D.G 111

Haptoglobin Groups and Transferrin Subtypes in Multiple Myeloma

Mitchell, R.J.; Carzino, R 117

Short Communications

The NFLD Antigen in Japan

Okubo, Y.; Yamaguchi, H.; Seno, T.; Egashira, S.; Green, C.A.; Kaita, H 122

AK, PGMi and 6PGD Polymorphisms in Central Sardinia

Masala, R.F.; Lunesu, M.; Ristaldi, M.S.; Succa, V.; Vona, G 125

Announcement 128

No. 3 Original Paper

Birth Weight and Natural Selection: An Example of Selection Relaxation in Man

Ulizzi, L.; Manzotti, C 129

Genetic Studies of Human Apolipoproteins. III. Polymorphism of Apolipoprotein C-II

Sepehrnia, B.; Kamboh, M.I.; Ferrel, R.E 136

Associations between the Two Serum Proteins Haptoglobin and Transferrin and Leukaemia

Mitchell, R.J.; Carzino, R.; Janardhana, V 144

Multiple Restriction Site Polymorphism at the Human Somatostatin Locus: A Population

Study in Italy

Palmarino, R.; Mantuano, E.; Arnone, M.; Palombaro, G.; Lucarelli, P 151

Studies on the Human Chromosome 3 Centromere with a Newly Cloned Alphoid DNA

Probe

Delattre, O.; Bernard, A.; Malfoy, B.; Marlhens, F.; Viegas-Pequignot, E.; Brossard, C;

Haguenauer, O.; Creau-Goldberg, N.; Van Cong, N.; Dutrillaux, B.; Thomas, G. ... 156

Population Studies in Northern Sweden. XIII. The 6-Phosphogluconate Dehydrogenase

Polymorphism

Beckman, L.; Beckman, G.; Nylander, P.-0 168

Genetic Polymorphism of $0^{1 / 3} \mathrm{HS}-$ Glycoprotein in a French Population. Description of Two

New Rare Variants

Robinet-Lévy, M.; Yuasa, L; Umetsu, K.; Ikebuchi, J

IV Contents

Short Communications

Gc and C3 Polymorphisms in Central Sardinia

Gruppioni, G.; Lunesu, M.; Succa, V.; Vona, G 178

Haptoglobin Groups in Ovarian Carcinoma

Fröhlander, N.; Stendahl, U 180

Gc and PGM Subtypes in Northern Greece

White, I.; Pentzos-Daponte, A.; Roberts, D.F.; Kaligatsis, C183

Genetic Variations of Insulin-Like Growth Factor I in Italy 
Palmarino, R.; Mantuano, E.; Lucarelli, P 186

No. 4 Original Paper

Amelogenesis imperfecta: A Genetic Study

Bäckman, B.; Holmgren, G 189

Alpha-2-HS-Glycoprotein Polymorphism Detected in Human Urine by Isoelectric Focusing and Immunoblotting

Kishi, K.; Yasuda, T.; Ikehara, Y 207

Alpha-Thalassemia in Northern Thailand. Frequency of Deletional Types Characterized at the DNA Level

Hundrieser, L; Sanguansermsri, T.; Papp, T.; Flatz, G 211

Possible Influence of Major Gene Heterozygosity on Variation of Quantitative Traits

Bishop, G.R.; Mayo, O.; Beckman, L216

Family Studies of the E, kEıs Genotype for Plasma Cholinesterase

Whittaker, M.; Britten, J.J.; Vyas, A.B.; Hayes, T.C 228

Recognition of Two New Phenotypes Segregating the E|k Allele for Plasma Cholinesterase

Whittaker, M.; Britten, J.J 233

DNA Haplotypes and Frameworks Associated with the Beta-Globin Gene in the Kachari

Population of Assam (India)

Hundrieser, L; Deka, R.; Gogoi, B.C.; Papp, T.; Flatz, G 240

Three Japanese Families with Members Carrying C7 Silent Allele $(\mathrm{C} 7 * \mathrm{Q} 0)$. Possibility for an Association between $\mathrm{C} 7{ }^{*} \mathrm{Q} 0$ and $\mathrm{C} 6 * \mathrm{~B}$

Nishimukai, H.; Kitamura, H.; Takeuchi, Y.; Shinomiya, T.; Tamaki, Y 246

Interaction between ABO and Haptoglobin in a White Australian Population

Mitchell, R.J.; Eslick, C.J 251

Short Communications

Formal Genetics of Esterase D (EC 3.1.1.1.): Evidence for a Sex-Phenotype Association

Amorim, A.; Rocha, J.; Kömpf, J.; Ritter, H 255

Distribution of Transferrin Subtypes in Aragon (North-East Spain)

Martínez-Jarreta, B.; Castellano, M 258

No. 5 Original Paper

Hemoglobin E Distribution in Ten Endogamous Population Groups of Assam, India

Deka, R.; Reddy, A.P.; Mukherjee, B.N.; Das, B.M.; Banerjee, S.; Roy, M.; Dey, B.;

Malhotra, K.C.; Walter, H 261

Further Studies of the Plasma aiB-Glycoprotein Polymorphism: Two New Alleles and

Allele Frequencies in Caucasians and in American Blacks

Juneja, R.K.; Weitkamp, L.R.; Stratil, A.; Gahne, B.; Guttormsen, S.A 267

Contents

$\mathrm{V}$

DNA Polymorphisms of the Insulin Receptor Gene in Japanese Subjects with Non-InsulinDependent Diabetes mellitus

Li, S.R.; Oelbaum, R.S.; Stocks, J.; Galton, D.J 273

Rare Apolipoprotein E Variant Cosegregating with a Unique APOE-C1-C2 Haplotype in a Normolipidemic Family

Smit, M.; Kniiff, P. de; Sijts, A.; Klasen, E.C.; Frants, R.R.; Havekes, L.M277

Familial Porphyria Cutanea Tarda: Hybridization Analysis of the Uroporphyrinogen

Decarboxylase Locus 
Hansen, J.L.; O’Connell, P.; Romana, M.; Romeo, P.-H.; Kushner, J.P 283

Genetic Polymorphisms of Orosomucoid and Alpha-2-HS-glycoprotein in a Philippine

Population

Umetsu, K.; Yuasa, I.; Nishimura, H.; Sasaki, H.; Suzuki, T287

Population Studies in Northern Sweden. XIV. Variation of the A, A2BO Blood Group Gene

Frequencies

Nylander, P.-O.; Beckman, L.; Cedergren, B 291

Two Familial Cases of Dissociation of Saliva Lea Levels and Erythrocyte Lewis Types

Ogata, M.; Nakasono, I.; Iwasaki, M.; Kubo, S.; Suyama, H.; Narita, K.; Tsukazaki, T.;

Muta, 1303

Genetic Characterization and Origin of Tunisian Berbers

Chaâbani, H.; Cox, D.W 308

Glucose-6-Phosphate Dehydrogenase Deficiency in Saudi Arabia. A Study in Al-Ula

El-Hazmi, M.A.F.; Warsy, A.S 317

Short Communications

Restriction Fragment Length Polymorphism of the D1S1 Locus in Italy

Palmarino, R.; Mantuano, E.; Lucarelli, P 323

A PGM $1 * 1$ A Variant with a Reduced Activity

Suzuki, K.; Hishida, S.; Ito, S.; Miyazaki, T.; Matsui, K.; Matsumoto, H 326

No. 6 Obituary

Mogens Hauge $\dagger$

Green, A.; Holm, N.V.; Mikkelsen, M 329

Original Paper

Red Cell Polymorphisms in Sardinia

Rickards, O.; Biondi, G.; Fuciarelli, M.; Capucci, E.; Walter, H.; De Stefano, G.F. . 332 HLA

Antigens in the Uitoto Indians and an Urban Population of Colombia

Bernal, J.E.; Duran, C; Papiha, S.S 337

Population Studies in Northern Sweden. XV. Transferrin C Subtypes

Sikström, C; Nylander, P.-O.; Beckman, L 341

Correlation between Native and Desialyzed Forms of Orosomucoid

Montiel, M.D.; Carracedo, A.; López-Rodríguez, I.; Rodríguez-Calvo, M.S.; Blazquez-

Caeiro, J.L.; Concheiro, L 353

Apolipoprotein A-IV Polymophism in the Finnish Population: Gene Frequencies and

Description of a Rare Allele

Lukka, M.; Metso, J.; Ehnholm, C 359

C4A7: A New Variant of Human Complement C4

Abbal, M.; Paoli, F. de; Cuccia-Belvedere, M.; Martinetti, M

VI

Contents

ABO Blood Groups, Intestinal Alkaline Phosphatase and Haptoglobin Types in Patients with Serum Hepatitis

Padma, T.; Valli, V.V 367

Short Communications

Alpha-1-Antitrypsin and Transferrin Null Alleles in the Portuguese Population

Espinheira, R.; Geada, H.; Mendonça, J.; Reys, L 372

Phenotype Frequency of LKE in the Danish Population 
Møller, B.; Jørgensen, J 375

Evidence for a New Allele at the Esterase D (E.C. 3.1.1.1) Locus

Huckenbeck, W.; Bonte, W.; Weidinger, S 378

Letter to the Editor

Fit of Isolation by Distance Models: Curve Fitting

Barrai, $1 \quad 381$

Author Index 383

Subject Index 385

S. Karger $\cdot$ Medical and Scientific Publishers

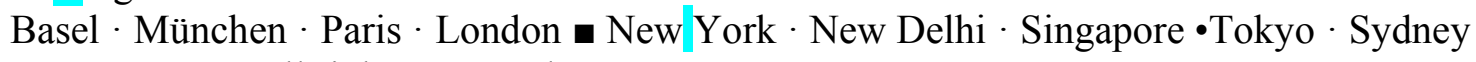

Drug Dosage All rights reserved.

The authors and the publisher have exerted every effort No part of this publication may be translated into other

to ensure that drug selection and dosage set forth in this languages, reproduced or utilized in any form or by any

text are in accord with current recommendations and means, electronic or mechanical,

including photocopy-

practice at the time of publication. However, in view of ing, recording, microcopying, or by

any information stor-

ongoing research, changes in government regulations, age and retrieval system, without

permission in writing

and the constant flow of information relating to drug

photocopying, direct

therapy and drug reactions, the reader is urged to check

Copyright Clearance

the package insert for each drug for any change in indica- Center (see 'Information for Readers

and Subscribers'),

tions and dosage and for added warnings and precau

tions. This is particularly important when the recom-

mended agent is a new and/or infrequently employed

(C) Copyright 1988 by

Basel (Switzerland)

drug. Printed in Switzerland by Buchdruckerei

Basler Zeitung+ Basler Nachrichten AG, Basel

S. Karger AG, P.O. Box, CH-4009 